\title{
LA RESPONSABILIDAD CIVIL DEL ABOGADO: ALGUNAS CONSIDERACIONES SOBRE SU NATURALEZA JURÍDICA, EL INCUMPLIMIENTO, LA CONFIGURACIÓN DEL DAÑO Y SU CUANTIFICACión en el DeRecho eSpañol
}

\section{THE CIVIL LIABILITY OF THE LAWYER: SOME CONSIDERATIONS ABOUT ITS LEGAL NATURE, NON-COMPLIANCE, DAMAGE CONFIGURATION AND ITS QUANTIFICATION IN SPANISH LAW}

Adela Serra Rodríguez* Trabajo recibido el 25 de marzo de 2019 y aprobado el 4 de diciembre de 2019

\section{ResUMEN}

La exigencia de responsabilidad civil al abogado que no ajusta su conducta a la lex artis es un fenómeno creciente en Europa y, especialmente, en España. Estas demandas exigen acreditar el incumplimiento o la negligencia del abogado, el daño y la relación de causalidad entre aquel y este. En este trabajo nos centraremos en la identificación del daño en aquellos supuestos en que el abogado con su conducta priva al cliente del derecho a que su pretensión sea examinada por los tribunales, del acceso a la tutela judicial, planteándose, además, cómo se ha de calificar y valorarse el daño por la pérdida de la oportunidad, atendiendo a los pronunciamientos judiciales.

Palabras clave: responsabilidad civil, abogados, lex artis, negligencia profesional, daños, pérdida de oportunidad procesal.

\begin{abstract}
The requirement of civil liability for lawyers is a growing phenomenon today in Europe and, especiaIly, in Spain. These demands require proof the negligence of the lawyer, the damage and the causal link between both of them. This paper will focus on identifying the damage suffered by the client when the lawyer deprives him of his right to have the claim examined by courts. Also, how the tribunals value the damage from chance loss applying different criteria.
\end{abstract}

Keywords: Civil liability, lawyers/attorneys, professional negligence, lex artis, damages, procedural chance loss.

\footnotetext{
Adela Serra Rodríguez, Doctora en Derecho y Catedrática de Derecho Civil, Universitat de València, España. Correo de con-
} tacto: adela.serra@uv.es 


\section{Consideraciones generales}

Actualmente los servicios prestados por profesionales liberales han devenido en objeto de tráfico jurídico de gran trascendencia económica y social. Esta realidad ha tenido reflejo en el paulatino incremento de los conflictos que suscitan este tipo de relaciones y, en particular, los relativos a la responsabilidad civil profesional.

Como no podía ser de otra manera, los profesionales del Derecho no han quedado ajenos a este fenómeno y, como ya sucediera primero con arquitectos, luego con los médicos y demás profesionales sanitarios, es, desde hace ya unos años, la conducta profesional del abogado la que es objeto de numerosos pronunciamientos judiciales en España, en la línea de otros países del entorno europeo, en orden a su calificación de negligente y, en consecuencia, a afirmar la obligación de indemnizar los daños causados por tal comportamiento, esto es, su responsabilidad civil.

Los caracteres propios de la actividad desarrollada por estos profesionales dificultan, respecto de otros supuestos, la afirmación de su responsabilidad civil. Ésta pasa necesariamente por examinar si su conducta se ajustó a los parámetros exigibles según su lex artis, a la diligencia de un buen profesional. De otra parte, no cabe olvidar que la Ciencia del Derecho, cuyo conocimiento y aplicación constituye la base de la actividad de estos profesionales, no es una ciencia exacta, como las naturales, sobre la que se puede partir de premisas ciertas e indubitadas para llegar a conclusiones igual de ciertas e indubitadas. De ahí que no quepa afirmar, con carácter general, que el resultado desfavorable de un litigio o el fracaso de una pretensión sea imputable a la conducta negligente del abogado.

\section{LA CALIFICACIÓN DE LA RELACIÓN PROFESIONAL DEL ABOGADO}

\subsection{La naturaleza jurídica de la relación profesional}

De manera previa al análisis de los presupuestos de la responsabilidad civil del abogado, es preciso detenerse en la cuestión de la naturaleza jurídica de la relación entablada entre el abogado y el perjudicado, que posteriormente hará valer la pretensión indemnizatoria frente aquel. Su respuesta condicionará algunos aspectos relevantes del régimen de su responsabilidad civil (plazo de prescripción, organización de la pluralidad de responsables, criterio de imputación subjetiva, alcance de daños indemnizables, etc.).

La calificación jurídica que merece la relación entablada entre el abogado y su cliente ha sido objeto de estudio por la doctrina y la jurisprudencia española que la han encajado en distintas figuras, como el arrendamiento de servicios, el contrato de obra, el mandato, los contratos mercantiles de gestión (mediación, agencia, comisión), llegando incluso a definirlo como contrato innominado o atípico'. No hay que olvidar tampoco que el abogado puede prestar sus servicios por cuenta ajena, sujeto a una relación laboral común (abogado de empresa o institución), a través de la relación laboral especial al estar integrado en un despacho individual o colectivo, o en régimen de Derecho administrativo (abogados de Administraciones públicas). Por último, puede ejercer en grupo la profesión a través de una sociedad profesional o de otras formas de colaboración (por ejemplo, en un despacho multiprofesional integrado por economistas, abogados y graduados sociales), aplicándose, en tal supuesto, las previsiones de la Ley 2/2007, de 15 de marzo, de Sociedades Profesionales.

1 Vid. Alonso Pérez (1997); Serra Rodriguez (1999a); Crespo Mora (2005a).

SERRA RODRÍGUEZ, Adela. La responsabilidad civil del abogado: algunas consideraciones sobre su naturaleza jurídica, el incumplimiento, la configuración del daño y su cuantificación en el Derecho español. Revista Justicia y Derecho, Santiago, v. $2, n^{\circ} 2,2019$ 
En la práctica, las actividades asumidas por el abogado constituyen supuestos heterogéneos que pueden quedar subsumidos en la denominación genérica de "contratos de gestión" o de "servicios". En cuanto que el contrato de arrendamiento de servicios constituye el contrato tipo de los contratos de gestión, tanto la jurisprudencia como la doctrina han calificado mayoritariamente como arrendamiento de servicios el contrato entablado con el abogado, sobre todo en lo que se refiere a actuaciones procesales, sin perjuicio de que determinadas actuaciones encuentren su marco legal más adecuado en el contrato de obra (p. ej. el encargo de un dictamen o la elaboración de unas operaciones particionales hereditarias) o en el mandato (sobre todo, si se otorga representación).

Se produce con ello una situación algo paradójica: de una parte, se abandona mayoritariamente la idea de mandato como cauce adecuado para los servicios prestados por estos profesionales, alcanzándose cierto consenso en que deben quedar encuadrados en el ámbito de arrendamiento de servicios; y de otra, como consecuencia de esta calificación ha de acudirse a la parca regulación del Código Civil español -en adelante, CC- (arts. 1544 y 1583 a 1587), que sólo contempla la relación de servicios con criados y asalariados, cuyo estatuto jurídico se encuentra ahora en normas laborales, y que fueron concebidos para regular servicios manuales y no para profesiones liberales intelectuales [en esta línea, SSTS de 25.6.1998 (RJ 1998, 5013), 8.6.2000 (RJ 2000, 5098)].

Por ello, para integrar la relación jurídica entablada con el abogado habrá que acudir a las normas del Código civil sobre obligaciones y contratos en general, a las previstas en la Ley Orgánica del Poder Judicial (en adelante, LOPJ) y en la Ley de Enjuiciamiento Civil (en lo sucesivo LEC) que afecten a su actividad, así como a las normas estatutarias o reglamentarias y las de carácter deontológico dictadas por los Colegios profesionales², proponiéndose, también, una aplicación analógica de ciertas normas del contrato de mandato ${ }^{3}$.

\subsection{La responsabilidad derivada del incumplimiento de deberes profesionales: contractual o extracontractual}

A la vista de lo anterior, existiendo una relación jurídica entablada entre el profesional y el cliente, cualquiera que sea su naturaleza, la responsabilidad derivada del incumplimiento de sus obligaciones, por su negligencia o impericia, es contractual, debiéndose aplicar el régimen previsto en los arts. 1101 y ss. CC, lo que tiene trascendencia, entre otros efectos, en la determinación de la cuantía indemnizatoria, por la limitación prevista por el art. 1107 CC para el deudor de buena fe, o en el plazo de prescripción de la acción ${ }^{4}$, como ha venido confirmando la jurisprudencia 5 .

Sin embargo, puede suceder que el abogado no estén unido con el demandante por relación contractual alguna, porque preste sus servicios obligatoriamente como letrado de turno oficio, en virtud

2 Real Decreto 685/2001, de 22 de junio, por el que se aprueba el Estatuto General de la Abogacía Española (en adelante, EGA); Código Deontológico de la Abogacía española, aprobado por el Pleno del Consejo General de la Abogacía Española, de 27 de septiembre de 2002, modificado el 10 de diciembre del mismo año, y el recién aprobado por el Consejo General de la Abogacía Española Código Deontológico de 6 de marzo de 2019.

3 Serra Rodriguez (1999a), pp. 172-174; Crespo Mora (2005a), p. 103. En esta misma línea, las SSTS 23.5.2006 (RJ 2006, 5827), 26.2.2007 (RJ 2007, 2115), 22.10.2008 (RJ 2008, 5787).

4 SeRra Rodriguez (2001b), pp. 157-ss.

5 SSTS 4.2.1992 (RJ 1992, 819), 17.11.1995 (RJ 1995, 8735), 12.5.1997 (RJ 1997, 3838), 28.1.1998 (RJ 1998, 357), 25.3 .1998 (RJ 1998, 1651), 8.2.2000 (RJ 2000, 842), 8.6.2000 (RJ 2000, 5098), 23.5.2001 (RJ 2001, 3372), 2.2.2001 (EDJ 2001, 37636$), 25.4 .2002$ (EDJ 2002/10139), 12.12.2003 (RJ 2003, 9285), 28.4.2005 (RJ 2005, 3646), 14.7.2005 (RJ 2005, 6532), 27.7.2006 (RJ 2006, 6548). En alguna ocasión la existencia de un seguro de responsabilidad civil del abogado ha llevado al perjudicado a fundamentar su pretensión indemnizatoria en el art. 1902 CC y los preceptos estatutarios correspondientes, a pesar de la existencia indubitada de una relación contractual, al ejercitar la acción directa contra la aseguradora [STS 14.5.1999 (RJ 1999, 3106)].

SERRA RODRÍGUEZ, Adela. La responsabilidad civil del abogado: algunas consideraciones sobre su naturaleza jurídica, el incumplimiento, la configuración del daño y su cuantificación en el Derecho español. Revista Justicia y Derecho, Santiago, v. 2, n०2, 2019 
de las exigencias legales y reglamentarias (arts. $32.4^{\circ}$ y 33 LEC, art. 440-2० LOPJ, art. 45 EGA) o prestarlos gratuitamente (en cuyo caso estaríamos ante un contrato atípico, atendiendo al art. 1544 CC). En otros casos, la conducta del abogado puede dañar a terceros ajenos a la relación entablada con su cliente. En tales supuestos, se plantea la doctrina cuál debe ser la calificación de la responsabilidad civil en que puede incurrir el profesional, si contractual o extracontractual.

Por lo que se refiere al abogado inscrito en el turno de oficio, organizado por el Colegio profesional correspondiente, algunas sentencias han afirmado que por el solo hecho de ser designado de oficio no puede excluirse la existencia entre él y su patrocinado de una verdadera relación de servicios, y aunque a este último le venga reconocido el derecho a la asistencia jurídica gratuita, la relación seguirá siendo de arrendamiento de servicios, «aunque en principio, de carácter gratuito». Al respecto, se ha apuntado que cabe diferenciar si al "cliente" del abogado de oficio le ha sido reconocido o no el derecho de asistencia jurídica gratuita7. Por ello, pueden existir "clientes" de abogados y procuradores de oficio sin derecho a la asistencia jurídica gratuita, por lo que vendrán obligados a satisfacer los honorarios al profesional (cfr. art. 33.2 LEC).

Si el "cliente" del abogado tiene derecho a asistencia jurídica gratuita, de la conducta dañosa del profesional deberá responder la Administración Pública, al desempeñar aquél un servicio público, siempre que tal conducta haya ocasionado un daño efectivo, evaluable económicamente e individualizado [cfr. arts. 26 Ley de Asistencia Jurídica Gratuita (en adelante, LAJG) y 32.1 Ley de Régimen Jurídico del Sector Público (en adelante, LRJSP)]8. El abogado no responderá personalmente de su negligencia o impericia, sino que responderá "objetivamente" la Administración por funcionamiento anormal del servicio de asistencia gratuita (prestado a través de los Colegios profesionales), siendo, además, competente la jurisdicción contenciosa-administrativa.

Sin embargo, si al litigante no se le ha reconocido el derecho de asistencia jurídica gratuita, teniendo, por tanto, obligación de pagar los honorarios y derechos a los profesionales del turno de oficio que se le hayan designado entiende la doctrina que deberá responder personalmente el profesional de los daños causados por su conducta, calificando, en tal caso, la responsabilidad de contractual, pues basta que exista una previa relación entre el causante del daño y el perjudicado para que así se califique9.

De otra parte, aun cuando el abogado preste gratuitamente sus servicios, por razones de amistad o parentesco, es incontrovertido que continúa sujeto al deber de realizar diligentemente las actividades que le imponga la defensa, con el máximo celo y diligencia, en virtud de lo establecido en el art. 1104 CC y las normas estatutarias correspondientes, de modo que el incumplimiento de estas obligaciones de carácter legal desencadenará su responsabilidad civil, siendo aplicable las normas de la responsabilidad

6 En este sentido, las SSAP de Málaga de 26.4.1996 (AC 727, 1996) y León de 17.3.1997 (AC 1997, 422).

7 Vid. el análisis de CreSPO Mora (2005a), pp. 271-307. Téngase en cuenta que el derecho a la asistencia jurídica gratuita sólo se reconoce a las personas físicas o jurídicas que reúnan los requisitos previstos en el art. $3^{\circ}$ Ley 1/1996, de 10 de enero, de Asistencia Jurídica Gratuita (LAJG), esto, es cuando acrediten insuficiencia de recursos para litigar.

8 CRespo Mora (2005), pp. 279 y ss. Dispone el art. 26 LAJG: "En lo que afecta al funcionamiento de los servicios de asistencia jurídica gratuita, los Colegios de Abogados y Procuradores están sujetos a los mismos principios de responsabilidad patrimonial establecidos para las Administraciones Públicas por la Ley 30/1992, de 26 de noviembre, de Régimen jurídico de las Administraciones Públicas y Procedimiento Administrativo Común" (actualmente, la Ley 40/2015, de 1 de octubre, de Régimen Jurídico del Sector Público).

9 CReSPo Mora (2005a), pp. 287-303. En esta línea, la anteriormente citada SAP León de 17 de marzo de 1997 (AC 1997, 422) sostiene que "por el hecho de que a una persona se le nombren los referidos profesionales de oficio e incluso aunque después se le reconozca el derecho a litigar gratuitamente, no por ello y por esos solos hechos puede predicarse que no hay relación contractual entre éstos últimos y su cliente", concluyendo que el plazo para exigir responsabilidad es el de quince años, de acuerdo con el art. 1964 CC (en su versión anterior a la Ley 42/2015), y no el del año del art. 1968 CC, previsto para las acciones dimanantes de la culpa extracontractual.

SERRA RODRÍGUEZ, Adela. La responsabilidad civil del abogado: algunas consideraciones sobre su naturaleza jurídica, el incumplimiento, la configuración del daño y su cuantificación en el Derecho español. Revista Justicia y Derecho, Santiago, v. 2, n०2, 2019 
contractual [SSTS 16.12.1996 (RJ 1996, 8970) y 12.12.2003 (RJ 2003, 9285)]. Además, según reiterada jurisprudencia no es imprescindible la fijación del precio en el momento de celebración del contrato para tener por cumplido el requisito de precio cierto, pudiendo ser determinado posteriormente, "durante o al final del contrato" [SSTS 20.11.2003, 18.2.2005 (RJ 2005, 1682)], conforme a los usos, a la equidad o, en su momento, a las tarifas orientadoras publicadas por los Colegios profesionales ${ }^{10}$. Por ello, se estima que la renuncia a los honorarios, fundada en una pura liberalidad, exige pacto expreso, existiendo, por tanto, una presunción de onerosidad en la prestación de los servicios del abogado, de tal modo que, si no consta exteriorizada la declaración unilateral de no cobrar los honorarios, la decisión a posteriori de exigir el precio de sus servicios se considera legítima.

En los supuestos en que el letrado desempeñe su actividad, de forma estable y en régimen de dependencia, quedando sometido a la organización de una empresa (sindicato o asociación) o de un despacho de abogados y, por tanto, sujeto a una relación laboral común o especial podrá incurrir en responsabilidad cuando con su actuación ocasione daños al cliente que contrató los servicios del despacho de abogados u otro empleador en el que aquél desarrolla su actividad profesional. Pese a que, en la práctica, es usual demandar al empleador con base en el art. 1903.4 CC y al abogado dependiente ex art. 1902 CC, e incluso, por el art. 1101 CC 11 , es más correcto, a mi juicio, considerar que en esta hipótesis estaríamos ante una responsabilidad contractual indirecta del deudor (empleador) por hecho de sus dependientes o auxiliares (aquí, el abogado)12. Su afirmación exige la concurrencia de determinados presupuestos: existencia de una relación obligatoria entre el empleador del abogado (deudor) y el cliente (acreedor), a la que el auxiliar (el abogado) es ajeno; intervención del auxiliar a iniciativa o por voluntad del deudor; conexión entre la actividad dañosa del abogado y el cumplimiento de la prestación asumida contractualmente por el empleador frente al perjudicado y, por último, la actuación negligente del abogado auxiliar o dependiente. A estos efectos por "auxiliar" cabe entender no sólo el sujeto dependiente jurídicamente del deudor principal, sino también aquel que de alguna manera "colabora" o interviene en el cumplimiento de la obligación asumida por el deudor, aun cuando no le una vínculo de subordinación alguno (cfr. art. 42 EGA), pudiendo incluso comprender al sustituto del deudor ${ }^{13}$, teniendo cabida, sin mayores problemas, en dicho concepto el abogado dependiente que presta sus servicios en el seno de una organización (por una relación laboral común o especial).

Sólo cuando la conducta dañosa originadora de responsabilidad del profesional se produzca con total abstracción de la obligación contractual, esto es, suponga la violación del genérico deber de «neminem laedere» podría calificarse su responsabilidad de extracontractual. Así, en aquellos supuestos en que con su comportamiento lesione derechos e intereses de terceros sin que exista o incluso, existiendo, al mismo tiempo, violación de las obligaciones asumidas contractualmente. Tal sería el supuesto, por ejemplo, del abogado que, infringiendo su deber de confidencialidad, cause perjuicios no sólo a su cliente -frente al que incurrirá en responsabilidad contractual-, sino a terceros ajenos a su relación con éste -que deberá calificarse de responsabilidad extracontractual-; o del abogado que vertiera expresiones injuriosas o contra el honor de un colega que defendiera a la parte contraria.

10 Sin embargo, tras la reforma operada por la Ley 25/2009, de 22 de diciembre, se prohíbe a los Colegios profesionales establecer baremos orientativos, ni cualquier otra recomendación sobre honorarios profesionales, salvo a los exclusivos efectos de tasación de costas y jura de cuentas de los abogados (art. 14 y Disposición Adicional 4a Ley 2/1974, de 13 de febrero, sobre Colegios Profesionales).

11 STS 23.12.1992 (RJ 1992, 10715) y 9.7.2004 (RJ 2004, 5121).

12 Para un análisis de estos supuestos y sus consecuencias jurídicas vid. SerRa RodríGuez (2008c). En el mismo sentido, CRESPO Mora (2005a) 317-320 y 340-341, y en CRESPO Mora (2005b), pp. 251 y 252. Así lo entendió, también, la SAP Madrid de 3 de octubre de 2006 (JUR 2007, 54870), para la actuación negligente del graduado social y su empleadora.

13 YZquierdo Tolsada (2004b), p. 48.

SERRA RODRÍGUEZ, Adela. La responsabilidad civil del abogado: algunas consideraciones sobre su naturaleza jurídica, el incumplimiento, la configuración del daño y su cuantificación en el Derecho español. Revista Justicia y Derecho, Santiago, v. 2, n० 2, 2019 
Cuando el abogado o el procurador ocasionen daños al cliente con su conducta, tipificada como delito (de obstrucción a la justicia o deslealtad profesional), la normativa aplicable será la prevista en los arts. 109 y ss. Código Penal, sobre responsabilidad civil derivada de delito, lo que ha suscitado en la doctrina un debate en torno a la naturaleza de la responsabilidad (contractual o extracontractual) consagrada en aquellos preceptos, dadas las diferentes consecuencias que se derivan, sobre todo, respecto del plazo de prescripción de la acción ${ }^{14}$.

\section{LOS PRESUPUESTOS DE LA RESPONSABILIDAD CIVIL DEL ABOGADO}

Según el art. 442.1 LOPJ los abogados y procuradores están sujetos en el ejercicio de su profesión a responsabilidad civil, penal y disciplinaria, según proceda. El art. 78.2 EGA prevé que los abogados en su ejercicio profesional están sujetos a "responsabilidad civil cuando por dolo o negligencia dañen los intereses cuya defensa les hubiere sido confiada, responsabilidad que será exigible conforme a la legislación ordinaria ante los Tribunales de Justicia, pudiendo establecerse legalmente su aseguramiento obligatorio". Pero para poder afirmar la responsabilidad civil del abogado se precisa de la concurrencia de estos presupuestos: incumplimiento de los deberes profesionales, daño y relación de causalidad (e imputación objetiva) entre el primero y el segundo. A diferencia de otros sectores de actividades profesionales, como la de los médicos, en la que la responsabilidad civil en determinados supuestos tiende a objetivizarse, a través de la inversión de la carga de la prueba o la doctrina del daño desproporcionado, tratándose de la actividad típica del abogado la responsabilidad civil es nítidamente subjetiva, basada en su culpa o negligencia, que opera como criterio de imputación subjetiva de responsabilidad [SSTS 27.7.2006 (RJ 2006, 6548), 21.6.2017 (RJ 2007, 3783)].

\subsection{El incumplimiento del abogado: tipificación de conductas negligentes}

Al tratar este primer presupuesto es inevitable referirse a la conocida distinción entre obligaciones de medios o de actividad y obligaciones de resultado, que tiene incidencia relevante en la misma noción del incumplimiento material y en la distribución de la carga de la prueba. En el primero de los supuestos, el abogado tan sólo vendría obligado a ejecutar la prestación empleando la diligencia "media" del buen profesional, ajustando su conducta a las reglas de la "lex artis ad hoc" y pericia exigible atendiendo a la naturaleza de la obligación y las circunstancias, con independencia del resultado último de su actividad diligente, que no vendría comprometido. En cambio, en las obligaciones de resultado, la consecución de éste se erige en parámetro de la exactitud del cumplimiento. Su no obtención se considera suficiente para tener por acreditado el incumplimiento.

La jurisprudencia ha considerado que la prestación del abogado constituye objeto de una obligación de medios o de actividad, al mismo tiempo que se enmarca su prestación en el arrendamiento de servicios $^{15}$. El abogado no está obligado a la satisfacción del interés último del acreedor, como puede ser

14 Sin embargo, pone de relieve CRESPO Mora (2005a), p. 257, la Sala Primera del Tribunal Supremo sostiene mayoritariamente que el plazo de prescripción para exigir la responsabilidad civil derivada de delito es de quince años, por aplicación del art. 1964 CC (anterior al 2015). Para la autora si el acto constitutivo del delito guarda una conexión con el contrato que vincula al profesional y al cliente la responsabilidad será contractual, debiendo aplicarse las normas del Código civil y del Penal (ob. cit., p. 259). 15 Entre otras, las SSTS 25.3.1998 (RJ 1998, 1651), 25.6.1998 (RJ 1998, 5013), 7.5.1999 (RJ 1999, 3368), 7.2.2000 (RJ 2000, 283), 12.12.2003 (RJ 2003, 9285), 14.7.2005 (RJ 2005, 6532), 14.12.2005 (RJ 2005, 1225), 30.32006 (RJ 2006, 2129), 26.2.2007 (RJ 2007, 2115), 22.4.2013 (RJ 2013, 3690).

SERRA RODRÍGUEZ, Adela. La responsabilidad civil del abogado: algunas consideraciones sobre su naturaleza jurídica, el incumplimiento, la configuración del daño y su cuantificación en el Derecho español. Revista Justicia y Derecho, Santiago, v. $2, n^{\circ} 2,2019$ 
la obtención de una sentencia favorable en el litigio o el reconocimiento de su pretensión, a pesar de que, como consecuencia del cumplimiento de su prestación, se pudiera obtener. Este último resultado no es exigible al profesional, porque es aleatorio o eventual, no depende exclusivamente de su actuación diligente, sino de la actuación o convicción del órgano jurisdiccional [SSTS de 12.12.2003 (RJ 2003, 9285). 30.3.2006 y 23.2.2010 (RJ 2010, 4341)] o de la propia "bondad" o "acierto" de la pretensión ejercitada. Ahora bien, la complejidad de la actividad típica del abogado abarca múltiples actuaciones (desde procesales hasta el mero asesoramiento) que pueden concebirse como resultados u obras en sí mismas. Así, en cualquier contrato de servicios profesionales habrá parciales y fragmentarios resultados exigibles, cuya ausencia servirá de pauta para tener por acreditado el incumplimiento de la global obligación de actividad (p. ej. el abogado que ejerce la defensa en el juicio asume una obligación de medios, pero determinadas prestaciones deben reputarse de resultado, como la asistencia a vistas o presentación de un escrito en plazo) ${ }^{16}$.

En algunas ocasiones, sin embargo, el abogado se compromete a la obtención de un resultado, de una obra en sí (opus), como sucede cuando asume el encargo de la elaboración de un informe o un dictamen jurídico o a la formalización o redacción de documentos, lo cual no significa que se obligue a la consecución de la pretensión última fundamentada en tal obra, que cae fuera de la prestación comprometida.

En relación con la distribución de la carga de la prueba se ha mantenido que para las obligaciones de medios y las de resultado rigen principios diversos. En virtud de las reglas sobre distribución de la carga de la prueba -art. 217 LEC- corresponderá al actor (cliente-acreedor), como hechos constitutivos de su pretensión indemnizatoria, la carga de la prueba del incumplimiento de la obligación por el profesional, el daño sufrido y la relación de causalidad entre el incumplimiento y el daño [STS 21.6.2007 (RJ 2007, 3781) y 23.10.2010 (RJ 2010, 4341)]. Por ello, siendo la obligación de medios el actor deberá probar la falta de diligencia del profesional, su imprudencia o impericia en la ejecución de la prestación. Si se prueba su culpa o negligencia se habrá acreditado el incumplimiento, lo que permitirá al cliente oponer la excepción de contrato no cumplido o cumplido defectuosamente ante la pretensión de cobro de los honorarios del abogado. Sin embargo, para afirmar su responsabilidad será preciso acreditar la realidad del daño y la relación de causalidad entre aquel incumplimiento y este, extremos ambos que presentan cierta complejidad y constituyen el principal obstáculo para el cliente perjudicado que desea plantear una reclamación por responsabilidad civil al profesional.

Frente a la pretensión indemnizatoria el profesional sólo podrá exonerarse, demostrando: 1) que los daños alegados no fueron causados por su conducta negligente, esto es, que no hay una relación de causalidad entre aquellos y ésta, porque los daños fueron ocasionados por un suceso extraño, inevitable e imprevisible (fuerza mayor), por la conducta del propio perjudicado ${ }^{17}$ o de un tercero ${ }^{18}$, e incluso por la falta de

16 Para un exhaustivo análisis de la configuración de la obligación del abogado como de medios o de resultado y sus consecuencias, vid. Serra Rodríguez (1999a), pp. 30-59 y 131-147, y en (2001 b), pp. 163-186, y Crespo Mora (2005a), pp. 81-89.

17 No puede imputarse responsabilidad al abogado cuando su error procede de los datos suministrados por su cliente [STS 26.2.2007 (RJ 2007, 2115)]. Tampoco si el daño que se pretende imputar (la desestimación de la demanda en que se ejercitaba una acción reivindicatoria) es debida a circunstancias objetivas relacionadas con la dificultad de identificación de las fincas reivindicadas y la complejidad de la reparcelación que las había afectado -hecho ajeno al control de la actividad del letrado- y a las circunstancias subjetivas relacionadas con el desconocimiento por los demandantes de la ubicación físicas de aquéllas [STS 23.2.2010 (RJ 2010, 4341)].

18 Así, para la STS 14.7.2010 (RJ 2010, 6045) no es imputable al abogado las consecuencias dañosas derivadas de haber dirigido la acusación penal contra persona distinta de la causante del siniestro, al apreciarse "una dificultad objetiva en la determinación del sujeto responsable contra quién debía dirigirse la demanda, derivado de la intervención de un tercero con especial autoridad, la Inspección de Trabajo, al elaborar el correspondiente informe en el que se identificaba al propietario como persona que manejaba la grúa".

SERRA RODRÍGUEZ, Adela. La responsabilidad civil del abogado: algunas consideraciones sobre su naturaleza jurídica, el incumplimiento, la configuración del daño y su cuantificación en el Derecho español. Revista Justicia y Derecho, Santiago, v. 2, n०2, 2019 
acierto no susceptible de ser corregida por medios procesales o la actuación judicial ${ }^{19}$; o 2) que su conducta, aun negligente, no ha ocasionado daños al demandante. Más sencilla parece a priori la prueba del incumplimiento, tratándose de una obligación de resultado. Al cliente le bastará acreditar que dicho resultado no se ha obtenido, sin necesidad de demostrar la negligencia o la culpa del profesional. Para exonerarse de responsabilidad, corresponderá al abogado la prueba de que el incumplimiento (la no consecución del resultado comprometido) no fue debido a su conducta, sino a un suceso extraño a su círculo de influencia, esto es, a fuerza mayor (p. ej.: el abogado no pudo entregar el dictamen ya realizado porque un corte eléctrico destruyó todos los ordenadores que contenían todas las copias, incluso las de seguridad), a la conducta del perjudicado (p. ej. no le dio los datos necesarios para elaborar correctamente el dictamen) o al hecho de un tercero del que no deba responder (p. ej. un tercero provoca un incendio que destruye su informe).

Llegados a este punto, resulta ilustrativo sistematizar las conductas de los letrados que los tribunales españoles han considerado negligentes -y, por tanto, configuradoras de incumplimiento contractual- $y$, cuando, por el contrario, han estimado que se ajustaban a la "lex artis ad hoc", a los parámetros de la diligencia exigible en el caso concreto. Esta exposición de casos-tipo o "familias de casos" resulta de indudable interés, ya que, de un análisis de la jurisprudencia, se desprende que la determinación de si hubo o no culpa en la conducta del abogado o del procurador y la fijación de la cuantía indemnizatoria divergen según el tipo de incumplimiento, del concreto deber infringido por estos profesionales ${ }^{20}$.

A) En primer lugar, el incumplimiento imputable al profesional puede consistir en la errónea interpretación de una norma jurídica. Ahora bien, como sabemos, en Derecho es frecuente que, ante un mismo supuesto conflictivo, la doctrina y la jurisprudencia propongan más de una solución. Por ello, si la cuestión suscitada es controvertida y el letrado opta, para resolverla, por una de las soluciones respaldadas por la doctrina y la jurisprudencia, no podrá ser calificado de imperito o negligente; no habrá, en consecuencia, incumplimiento ${ }^{21}$. Sin embargo, si existen varias interpretaciones de la cuestión discutida el abogado deberá adoptar la "postura menos arriesgada para los intereses de su cliente"22.

Esto demuestra que no todo error profesional supone por sí impericia o negligencia, ni mucho menos responsabilidad, sino que para ello sea así dicho error tendrá que ser "inexcusable"; esto es, tiene que ser imputable a una falta evidente y relevante de diligencia, a su impericia, negligencia o imprudencia, que será valorada en atención a un modelo medio de diligencia y teniendo en cuenta, al mismo tiempo, las circunstancias concurrentes en la obligación (que podrán haber exigido, sin embargo, una atención especial o superior a la media) $)^{23}$.

B) En segundo lugar, la mayoría de los supuestos en los que se suscita la responsabilidad del letrado traen causa en "conductas omisivas" o extemporáneas que ocasionan al cliente los daños que se pretenden indemnizar. En estos casos, el mayor obstáculo para estimar la pretensión indemnizatoria deriva de la prueba de la relación de causalidad entre la conducta del profesional (que, en la mayoría de los casos, sí que podrá ser calificada de negligente o imperita) y los daños alegados por el cliente, que suelen venir identificados con la pérdida de la oportunidad procesal.

19 STS 23.2.2010.

20 ÁNGEL YÁGÜEZ (2008), p. 3.

21 SSAP Huesca de 26.6.2000 (EDJ 2000/22883) y Segovia de 26.1.2000 (AC 2000, 96); SSTS 26.2.2007 (RJ 2007, 2115) y 23.3.2007 (RJ 2007, 1542).

22 STS de 30.12.2002 (RJ 2002, 333) y SAP Málaga de 13.1.1996 (AC 1996, 307).

23 Muestra de este razonamiento es la STS de 8.2.2000 (RJ 2000, 842), que confirmó la condena por responsabilidad civil del letrado que, en su actuación profesional en defensa de la actora, erró al calcular el plazo de caducidad para el ejercicio de la acción por despido improcedente no informando adecuadamente a su defendido. Dicha conducta evidencia, a juicio del Tribunal Supremo, una actuación profesional del abogado "carente de la diligencia debida", y ello, porque, aunque no se diga expresamente en la sentencia, dicho error es inexcusable, ya que la norma en tal sentido es clara y no da lugar a interpretaciones diversas.

SERRA RODRÍGUEZ, Adela. La responsabilidad civil del abogado: algunas consideraciones sobre su naturaleza jurídica, el incumplimiento, la configuración del daño y su cuantificación en el Derecho español. Revista Justicia y Derecho, Santiago, v. 2, n०2, 2019 
Dentro de este grupo, podemos distinguir a su vez, en atención a las consecuencias que se enlazan a estas omisiones, diversas hipótesis:

a) Aquellos supuestos en que la negligencia consiste en la omisión de la proposición de un medio útil para fundamentar la pretensión del cliente, o asegurar su resultado, o para oponerse a las pretensiones de la otra parte (si defiende los intereses del demandado), como, por ejemplo, la de oponer la excepción de cosa juzgada, de incompetencia judicial, de falta de listiconsorcio pasivo o activo necesario, alegar la caducidad o la prescripción de la acción, etc.

La constatación del incumplimiento del abogado, en estas hipótesis, no es tarea sencilla, ya que aquel no está obligado a un comportamiento determinado, sino genéricamente a actuar en dirección a un resultado (éxito de la posición defendida), que, sin embargo, no viene comprometido. La condición de profesional que ostenta el deudor le permite la elección de aquellos medios que considere más idóneos para la ejecución de su encargo [STS de 23.5.2001 (RJ 2001, 3372)]. Sin embargo, esta independencia o discrecionalidad técnica tiene siempre como límite la adecuación de la conducta del profesional a un modelo de profesional prudente y diligente, en aras satisfacer los intereses de su cliente. En suma, "aunque no toda deficiencia en dicha tarea es determinante de responsabilidad, sí lo es cuando, como sucede en el caso, se incurre en la omisión de alegación de un dato objetivo, ostensible e indefectible, de especial trascendencia para el resultado del proceso" [STS 30.11.2005 (RJ 2005, 7859)].

b) En otros supuestos, la conducta omisiva del abogado se traduce en la no observancia de los plazos legales, que desemboca en la no interposición en tiempo de la demanda ${ }^{24}$; o de un recurso (del recurso de casación ${ }^{25}$, del recurso de casación para unificación de doctrina ${ }^{26}$, del recurso de revisión ${ }^{27}, \ldots$..), provocando con ello el cierre de una vía o instancia procesal al dejar prescribir la acción ${ }^{28}$ o el delito, o devenir definitiva la resolución contra la que se pretendía recurrir.

Todos estos comportamientos omisivos -denominados por algunos autores "culpas de agenda"29- tienen en común que de ellos se derivan consecuencias graves para el cliente, al quedar precluída cualquier posibilidad de hacer valer sus derechos (o pretensiones) ante un órgano jurisdiccional (o, en el caso de los recursos, volver a hacer valer) ${ }^{30}$. La negligencia del profesional no estriba en el desconocimiento de especiales normas técnicas o interpretaciones jurisprudenciales, sino lisa y llanamente en la incuria, desidia o abandono de deberes básicos, manifestados en la omisión de las actuaciones descritas. Para la jurisprudencia, en tales casos, la obligación asumida por el profesional es de medios y no de resultado. Sin embargo, la pasividad del profesional o la realización extemporánea de un aislado acto procesal, que impide iniciar o continuar un procedimiento judicial donde dirimir el conflicto planteado y hacer valer el interés de su cliente, pone en evidencia que no ajustó su comportamiento al canon de diligencia exigible, esto es, su incumplimiento. Cuestión diversa será la de si se podrá hacer responsable al profesional de (todas) las consecuencias dañosas derivadas de dichas omisiones.

c) En ocasiones, la conducta del profesional consiste en la inejecución de una actuación aislada, que, a diferencia de los supuestos anteriores, no va encaminada a iniciar o proseguir un procedimiento judicial, sino que se inserta dentro de actividades no procesales o posteriores a una resolución judicial o admi-

24 SSTS 14.7.2003 (RJ 2003, 4630), 12.12.2003 (RJ 2003, 9285) y 9.7.2004 (RJ 2004, 5121).

25 SSTS 25.6.1998 (RJ 1998, 5013) y 8.7.2003 (RJ 2003, 4613).

26 STS 29.5.2003 (RJ 2003, 3914).

27 STS 26.1.1999 (RJ 1999, 323).

28 SSTS 16.12.1996 (RJ 1996, 8971), TSJ de Navarra de 9.12.1997 (RJ 1997, 9414).

29 Ángel YÁGüEz (2008), p. 9.

30 Tienen, también, cabida en estos supuestos la omisión por el abogado de un concepto indemnizable en una demanda por responsabilidad [STS 14.12.2005 (RJ 2006, 1225)].

SERRA RODRÍGUEZ, Adela. La responsabilidad civil del abogado: algunas consideraciones sobre su naturaleza jurídica, el incumplimiento, la configuración del daño y su cuantificación en el Derecho español. Revista Justicia y Derecho, Santiago, v. 2, n०2, 2019 
nistrativa ya firme. Tienen aquí cabida los casos en que el profesional no reclama en tiempo a un órgano administrativo ciertas cantidades ya acordadas por sentencia judicial firme ${ }^{31}$, o incluso, no ejecuta en plazo la sentencia firme que había concedido al cliente determinadas cantidades.

d) Por último, existen ciertas conductas omisivas que ni siquiera pueden ser consideradas como relevadoras de la negligencia o de la impericia del profesional y, por tanto, del incumplimiento. Así, se ha entendido por los tribunales para los supuestos de incomparecencia del letrado a la celebración de la vista en apelación ${ }^{32}$, o en el juicio de desahucio ${ }^{33}$, o la no comparecencia del letrado a la práctica de la prueba de confesión del cliente ${ }^{34}$; o la no personación en el acto de designación de perito.

C) En tercer lugar, junto a los supuestos, mayoritarios, en que la negligencia del profesional se traduce en conductas omisivas o tardías, existen otros en que su comportamiento se muestra erróneo para la finalidad que pretendía satisfacer, porque hay un defectuoso planteamiento técnico del asunto, revelador de la impericia y de la carencia de los especializados conocimientos que un técnico en materias jurídicas ha de poseer. Así, las hipótesis de proposición de demanda ante un juez evidentemente incompetente por razón de la materia o del territorio [STS de 14.2.2003 (RJ 2003, 2093)], la elección equivocada del procedimiento, la no citación de todos los demandados existiendo litisconsorcio pasivo necesario, etc.

No obstante, como hemos mantenido anteriormente, no todo error en la ejecución de su prestación constituye incumplimiento, desencadenante de responsabilidad, sino que aquél ha de poner de relieve una evidente impericia o descuido del profesional en el tratamiento o resolución de un problema de carácter técnico ${ }^{35}$.

D) Por último, especial relevancia adquiere como generador de responsabilidad el incumplimiento del deber de fidelidad que comprende, según la jurisprudencia, el deber de información, de guardar secreto, de custodiar la documentación y de entregarla una vez terminada la relación de servicios [STS 25.3.1998 (RJ 1998, 1651)].

El abogado, en la ejecución de su prestación, además de observar la diligencia o pericia exigibles, debe adoptar ciertas conductas de marcado carácter ético o deontológico, y que aparecen recogidos en las normas estatutarias. La idea de confianza que subyace en estas relaciones y la frecuente presencia de las cualidades personales del profesional ("intuitus personae") explica que estos deberes de comportamiento (lealtad, fidelidad y secreto), que derivan del principio de buena fe e integran las obligaciones del abogado, asuman una especial relevancia jurídica.

Cronológicamente la primera obligación que le incumbe al abogado es informar a su cliente "de pros y contras, riesgo del asunto o conveniencia o no del acceso judicial, costos, gravedad de la situación,

31 Así, las SSTS 28.1.1998 (RJ 1998, 357) y 3.10 .1998 (RJ 1998, 8587) estimaron la responsabilidad de los letrados al reclamar fuera de plazo al Fondo de Garantía Salarial (entidad administrativa) ciertas cantidades que habían sido acordadas judicialmente en virtud de sentencia firme.

32 STS 4.2.1992 (RJ 1992, 819).

33 STS 20.10.1989 (RJ 1989, 6947).

34 SAP Jaén 7.11.1994 (AC 1994, 1929).

35 Así, se ha considerado negligente al abogado que solicitó erróneamente pensión alimenticia en un proceso de divorcio en lugar de la compensatoria "sin caer en la cuenta de algo que debiera ser de sobra conocido por un profesional de la abogacía" [SAP de Valladolid de 14.10.1998 (AC 1998, 2260)]; o que propuso deficientemente la prueba en un juicio de alimentos, lo que repercutió en el retraso de su percepción [SAP de Pontevedra de 18.11.1996 (AC 1996, 2090)]; o, en fin, que no solicitó el recibimiento a prueba del incidente [SAP de La Rioja de 29.3.2000]. Sin embargo, no hay negligencia en la actuación de la abogada que al redactar un recurso de casación omitió justificar la relevancia de la infracción de las normas estatales o comunitarias europeas en el fallo de la sentencia que se pretendía recurrir, ya que es una de las "actuaciones profesionales que presenta más dificultad en la práctica procesal, sino la que más", atendiendo, además de que, la sentencia que se pretendía recurrir fundó la desestimación de la reclamación en una valoración probatoria [STS 20.5.2015 (RJ 2015, 2056)].

SERRA RODRÍGUEZ, Adela. La responsabilidad civil del abogado: algunas consideraciones sobre su naturaleza jurídica, el incumplimiento, la configuración del daño y su cuantificación en el Derecho español. Revista Justicia y Derecho, Santiago, v. 2, n०2, 2019 
probabilidad de éxito o fracaso..." [STS 23.5.2001 (RJ 2001, 3372)]. Este deber información se mantiene durante toda la relación con el cliente y si el profesional decide no continuar prestando el servicio por el que fue contratado, deberá informar al cliente del estado de la situación a fin de que pueda seguir defendiéndose ante quien corresponda.

No es suficiente cualquier información, sino que ésta ha de ser lo más completa posible y, además, clara, teniendo en cuenta que el cliente suele ser lego en la materia, debiendo asegurarse el profesional de que comprende su contenido [STS de 14.5.1999 (RJ 1999, 3106) ${ }^{36}$. El abogado debe informar, por tanto, de la existencia de las vías o cauces procesales que tiene el cliente para formular una pretensión o para continuar un procedimiento, interponiendo los recursos pertinentes ${ }^{37}$.

De otra parte, junto a este deber de información accesorio y previo al inicio de la ejecución de la obligación principal, al abogado puede corresponderle como obligación principal la de aconsejar o asesorar al cliente, sin llevar aparejado el compromiso de iniciar o continuar actividad jurisdiccional alguna. En estos casos, podrá calificarse de incumplidor o negligente al abogado que emita un consejo "inveraz o inexacto", al ofrecer información falsa o errónea, por no ajustarse a los dictados legales, líneas jurisprudenciales asentadas o desconocer la doctrina científica, teniendo en cuenta que, como hemos puesto de manifiesto, si la cuestión, objeto del estudio y asesoramiento, no está pacíficamente resuelta por las normas, ni la doctrina, ni la jurisprudencia no incurrirá en negligencia el profesional que opte por una de las soluciones ofrecidas. En suma, el consejo o asesoramiento erróneo constituye incumplimiento si el error es reconducible a la impericia o negligencia del abogado.

Junto a la obligación de información, destaca el deber de guardar secreto que no desaparece tras la extinción de la relación contractual, sino que permanece tras ella. Tal como prevén las normas estatutarias, el deber de secreto impuesto al abogado que, constituye al mismo tiempo, un derecho para él, se concreta en no revelar ningún hecho o noticia que conozca por razón de su actuación profesional (arts. 32 y 42 EGA). Su violación desencadenará la correspondiente responsabilidad disciplinaria y podrá, si se siguen daños y perjuicios, originar responsabilidad civil e incluso penal (delito de revelación y de descubrimiento de secretos -arts. 199 y 197 (P-).

Por último, el abogado debe custodiar diligentemente la documentación que referida a su cliente se haya originado en el desarrollo de su actividad profesional. Por consiguiente, una vez finalizada la relación contractual con su cliente habrá de entregarle, a su requerimiento, toda la documentación que pueda afectarle. Esta obligación es de inexcusable cumplimiento, aun cuando el cliente haya encomendado la dirección de sus asuntos a un nuevo letrado y el anterior le niegue la venia, ya que, si bien la «venia es una regla de cortesía, ..., no es una norma que impida el cumplimiento de preceptos del Derecho civil, ni, mucho menos, que sirva como arma de coacción frente al cliente que, tras la extinción del contrato precise y reclame información y devolución de documentación» [STS 25.3.1998 (RJ 1998, 1651)]. De este modo, la pérdida de la documentación imputable al abogado, a quien le incumbe su custodia, constituirá incumplimiento de sus obligaciones originando, en su caso, responsabilidad si se acreditan que los daños sufridos por el cliente son objetivamente imputables a tal conducta.

36 En esta Sentencia entendió el Tribunal Supremo que la diligencia exigida al letrado, que defendió a los actores en una diligencias penales abiertas por la muerte de su hijo, comprendía no sólo la comunicación a sus clientes de que las diligencias habían sido archivadas, sino también cerciorarse de la recepción de la misiva, de si sus clientes comprendían su contenido y, en consecuencia, informarles de los efectos jurídicos y vías procesales que, a partir de dicho momento, se abrían para su posible ejercicio en plazo.

37 Vid. Ángel YÁgüez (2008), pp. 4 y 5.

SERRA RODRÍGUEZ, Adela. La responsabilidad civil del abogado: algunas consideraciones sobre su naturaleza jurídica, el incumplimiento, la configuración del daño y su cuantificación en el Derecho español. Revista Justicia y Derecho, Santiago, v. 2, n०2, 2019 


\subsection{La configuración del daño y la relación de causalidad entre el incumplimiento profesional y el daño}

Uno de los mayores obstáculos para la estimación de las demandas de responsabilidad civil del abogado estriba en la demostración de la certeza del daño sufrido por el cliente y de la relación de causalidad y la imputación objetiva entre el incumplimiento del profesional y tal daño ${ }^{38}$. Sin daño no hay responsabilidad civil; por ello, su prueba deviene en presupuesto ineludible para su afirmación.

Ocurre, sin embargo, que el daño imputable al incumplimiento del abogado puede ser configurado de distinta manera, pudiendo venir identificado con la pérdida del litigio o la pretensión o posición defendida, con la pérdida de la oportunidad procesal o la privación del derecho a la tutela judicial efectiva. De la identificación, en cada caso, del daño sufrido por el cliente e imputable a la conducta del profesional dependerá el desenlace de la reclamación de responsabilidad civil.

En las dos últimas décadas se ha ido creando un cuerpo jurisprudencial en España sobre la responsabilidad civil del abogado, si bien la jurisprudencia no ha sido suficientemente clara en relación con la identificación del daño sufrido por el demandante, una vez apreciada la culpa o negligencia del abogado, su consideración como daño patrimonial o moral, su acreditación plena, así como los criterios para fijar su quantum indemnizatorio. No obstante, de la lectura de las resoluciones de los últimos años sí se puede observar cierto cambio en la jurisprudencia del Tribunal Supremo, que expondremos a continuación.

Así, en primer lugar, hay unanimidad entre las sentencias que niegan que el daño generado por la impericia o negligencia del abogado venga identificado con la falta de prosperidad de la pretensión del cliente deducida en el pleito, con la pérdida del litigio o la privación de la pretensión. La imposibilidad de acreditar un nexo de causalidad entre el incumplimiento y el daño así configurado justifican la desestimación de estas pretensiones indemnizatorias. Según el Tribunal Supremo emergerá la responsabilidad del abogado, cuando se acredite la relación de causalidad entre su incumplimiento y el daño, "sin que, por lo general, ese daño equivalga a la no obtención del resultado de la pretensión confiada o reclamación judicial: evento de futuro que, por su devenir aleatorio, dependerá al margen de una conducta diligente del profesional, del acierto en la correspondencia del objetivo o la respuesta judicial estimatoria o, en otras palabras, la estimación de la pretensión sólo provendrá de la exclusiva e intransferible integración de la convicción del juzgador" [SSTS 23.5.2001 (RJ 2001, 3372) y 12.12.2003 (RJ 2003, 9285)].

En segundo lugar, el daño puede identificarse con la "pérdida de la oportunidad" en todos aquellos supuestos en que el incumplimiento del profesional ha impedido definitivamente al cliente la prosecución normal de una instancia procesal, dejando prescribir o caducar las acciones y los derechos. Sin embargo, con tal aseveración, lejos de resolverse el problema surgen inmediatamente otras cuestiones: ¿es la pérdida de la oportunidad procesal un daño moral o material?; ¿cómo se demuestra la certeza de dicho perjuicio, requisito imprescindible de su resarcibilidad? Y, por último, ¿cómo se valora este daño? Al respecto, la jurisprudencia ha seguido diversas posiciones. A saber:

A) Para un grupo de resoluciones el daño por la pérdida de la oportunidad es un daño moral que se cuantifica económicamente por el Juez, según su prudente arbitrio, y sin conexión alguna con el montante de la pretensión frustrada por la conducta del profesional, sin entrar tampoco a valorar las probabilidades de éxito de la demanda o el recurso no interpuesto por la negligencia del abogado. De este modo, se desvincula el daño por la pérdida de la oportunidad del hipotético juicio sobre las pretensiones u actos

38 La imputación objetiva del daño a la conducta del abogado pretende limitar la mera causalidad física o material, seleccionado desde el punto de vista de valoración jurídica las consecuencias dañosas que pueden ser puestas definitivamente a cargo de su causante, atendiendo a criterios de razonabilidad, previsibilidad o causalidad adecuada.

SERRA RODRÍGUEZ, Adela. La responsabilidad civil del abogado: algunas consideraciones sobre su naturaleza jurídica, el incumplimiento, la configuración del daño y su cuantificación en el Derecho español. Revista Justicia y Derecho, Santiago, v. 2, n०2, 2019 
procesales omitidos por el letrado. Se afirma que para el tribunal que resuelve sobre el juicio de responsabilidad del abogado es imposible plantearse cuál hubiera sido el resultado (estimatorio o desestimatorio) de las acciones o recursos frustrados," pues ello pertenece al estricto campo de las conjeturas" 39 .

En efecto, las dificultades probatorias del daño concretado en la "pérdida de la oportunidad" han llevado, con cierta frecuencia, a los tribunales a sostener que la mera privación del derecho a iniciar o continuar el pleito, consecuencia de la conducta negligente del letrado, puede ser considerada en sí mismo un perjuicio, si bien de carácter moral. Ahora bien, este perjuicio moral y la pérdida de la oportunidad son daños cercanos pero diferentes. El resarcimiento del daño moral por la privación del derecho a la tutela judicial efectiva o, más correctamente, por privación del derecho a los recursos, de acceso a la tutela judicial o a que la pretensión sea examinada por los tribunales ${ }^{40}$, no exige la previa indagación de las oportunidades o expectativas del cliente. Dicho de otro modo, aún no existiendo dichas oportunidades, podría existir daño moral, porque al cliente se le impidió, por la actuación negligente del profesional, con carácter definitivo, su legítima expectativa a obtener un pronunciamiento de un órgano judicial.

Además, en ocasiones, este daño moral no existirá, a pesar de que los intereses económicos afectados por el conflicto judicial sean muy elevados, porque no se le ha privado definitivamente del acceso a los tribunales ${ }^{41}$. Tampoco habrá daño moral por la privación del derecho de acceso a los tribunales si, antes de encomendar el asunto al letrado, el cliente ya no contara con el citado derecho (por estar ya prescrito o caducada la acción) $)^{42}$.

B) En una línea parecida, pero no idéntica, otras sentencias califican de daño moral la pérdida de la oportunidad, pero toman como pautas para cuantificarlo diversos factores, entre los que se encuentran, la valoración de las expectativas del cliente, junto con los antecedentes y circunstancias concurrentes en el proceso en que se privó a aquél del acceso a la justicia (por ejemplo, cuantía de las costas, valor económico del asunto $)^{43}$.

El juicio sobre la prosperabilidad de la pretensión del cliente, frustrada por la conducta negligente del abogado o procurador, no se utiliza para acreditar la existencia del daño, calificado de moral, sino que es un criterio más para su cuantificación.

No obstante, hay sentencias que, calificando de moral el daño por la vulneración de la tutela judicial efectiva, consideran para que sea indemnizable "es procedente examinar... si, como consecuencia de la negligencia profesional, que debe resultar probada, se ha producido una disminución notable y cierta de probabilidades de defensa de la parte suficientes para ser configurada como una vulneración objetiva del derecho a la tutela judicial efectiva" [STS 30.3.2006 (RJ 2006, 2129)].

C) Otras sentencias, mayoritarias en los últimos años, califican el daño por la pérdida de la oportunidad como daño material o patrimonial, vinculando su valoración económica con la viabilidad de la

39 Así, la STS 11.11.1997 (RJ 1997, 7871), para un supuesto de responsabilidad de un procurador. En el mismo sentido, para responsabilidad del abogado, las SSTS 14.5.1999 (RJ 1999, 3106), 20.5.1996 (RJ 1996, 3793), 25.6.1998 (RJ 1998, 5013), 8.7.2003 (RJ 2003, 4613), 12.12.2003 (RJ 2003, 9285), 14.12.2005 (RJ 2005, 1225).

40 Pone de relieve Crespo Mora (2005a), pp. 402-404, que el daño por la privación del derecho a que la pretensión examinada por órganos jurisdiccionales no es una vulneración de la tutela judicial efectiva del art. 24 Constitución Española, ya que, según la interpretación mantenida por el Tribunal Constitucional (TC), la tutela judicial efectiva se satisface siempre que se obtenga una resolución fundada en Derecho, aunque sea de inadmisión del recurso o pretensión. Además, siguiendo al TC, el derecho a la tutela judicial efectiva sólo se tiene frente a los poderes públicos, y no frente a los particulares (el abogado al que se imputa la conducta negligente).

41 STS 14.2.2003 (RJ 2003, 2093).

42 CRespo Mora(2005a), p. 402, nota 153.

43 En tal sentido, las STSS 26.1.1999 (RJ 1999, 323) y 29.5.2003 (RJ 2003, 3914).

SERRA RODRÍGUEZ, Adela. La responsabilidad civil del abogado: algunas consideraciones sobre su naturaleza jurídica, el incumplimiento, la configuración del daño y su cuantificación en el Derecho español. Revista Justicia y Derecho, Santiago, v. 2, n०2, 2019 
pretensión frustrada por la conducta negligente del abogado o procurador, previo su completo examen, atendiendo a las circunstancias concurrentes en el caso concreto ${ }^{44}$.

Considero acertada esta última posición, en tanto que con la "pérdida de la oportunidad" no se trata de indemnizar al cliente unos lucros que hubiera podido obtener de haber visto estimada su pretensión (ya que esto, normalmente, no se podrá saber con certeza), sino de resarcir la privación de unas oportunidades serias y reales de obtener determinadas ventajas o resultados útiles ${ }^{45}$, e incluso de evitar determinados perjuicios o riesgos ${ }^{46}$, lo que tan sólo será posible si se constata que aquellas oportunidades existían. Este daño por la pérdida de la oportunidad no es identificable con el daño moral consistente en los padecimientos o sufrimientos del cliente a lo largo de un proceso, cuyo resultado se le aparece como incierto y que, según el criterio del riesgo general de la vida, no cabría imputar automáticamente a la conducta del abogado ${ }^{47}$.

Para esta línea jurisprudencial es necesario, para acreditar la existencia de daño indemnizable, que el órgano judicial realice el llamado "juicio sobre el juicio"48, por lo que sólo si tras él se concluye que el actor tenía "serias o razonadas probabilidades" de ver estimada su pretensión y de que éstas se frustraron por la conducta negligente del profesional habrá responsabilidad. Según el TS "La responsabilidad por pérdida de oportunidades exige demostrar que el perjudicado se encontraba en una situación fáctica o jurídica idónea para realizarlas" [STS 27.7.2006 (RJ 2006, 6548)]. Por ello, si no hay una "razonable certidumbre de la probabilidad del resultado no hay responsabilidad".

Este método del "juicio sobre el juicio" consiste en un estudio particular por el órgano que conoce de la demanda de responsabilidad civil de las probabilidades de éxito que, en el caso concreto, tenía el actor, esto es, "un cálculo prospectivo del buen éxito de la acción” [STS 22.4.2013 (RJ 2013, 3690), 24.4.2015 (RJ 2015, 2388), 1.7.2016 (RJ 2016, 3721)]. Implica, por tanto, un juicio de probabilidad sobre cuál hubiera sido el resultado final del conflicto de haber actuado el profesional con la diligencia y la pericia exigibles ${ }^{49}$.

Se ha dicho que la utilización de este método para valorar las probabilidades de éxito del cliente, en los casos de pretensiones no civiles (penales, administrativas o laborales) supondría realizar por parte del órgano jurisdiccional civil que conoce de la demanda de responsabilidad del letrado un juicio de probabilidad sobre otra jurisdicción que resulta "totalmente inadmisible". Sin embargo, no puede olvidarse que el ordenamiento jurídico prevé que los jueces resuelvan cuestiones prejudiciales aplicando normas ajenas a su ámbito jurisdiccional ${ }^{50}$.

44 SSTS 27.7.2006 (RJ 2006, 6548), 26.2.2007 (RJ 2007, 2115), 21.6.2007 (RJ 2007, 3781), 27.5.2010 (RJ 2010, 5160); 27.10 .2011 (RJ 2011, 7313), 22.4.2013 (RJ 2013, 3690), 19.11.2013 (RJ 2013, 7448), 24.4.2015 (RJ 2015, 2388), 1.7.2016 (RJ 2016, 3721).

45 Para Gómez Pomar (2003), pp. 5-7, la noción de "pérdida de la oportunidad" hace referencia al valor esperado, que resulta de la probabilidad de éxito y de la cuantía del pleito.

46 STS 18.2.2015 (RJ 2015, 1682).

47 Según este criterio al cliente no le pueden ser garantizados aquellos riesgos a los que se vería igualmente expuesto, aunque el incumplimiento del abogado no se hubiera producido. En tal sentido, Serra Rodríguez (2001b), p. 279; Crespo Mora (2005a), p. 387. Solamente, cuando la conducta del letrado ha incrementado el riesgo de producción del daño (la angustia, zozobra, ansiedad, frustración) podríamos hacerle responsable de ese daño moral. Es lo que movió al TS en su Sentencia de 20.5.2014 a reconocer a cada uno de los demandantes más de 60.000 euros en daños morales, "para compensar la zozobra e incertidumbre provocadas por la negligencia del abogado", que viéndose abocados a emprender actuaciones de resultado incierto, mientras quienes se encontraban en la misma situación que ellos como perjudicados del camping Las Nieves de Biescas obtenían una sentencia favorable del orden contencioso varios años antes.

48 Un análisis de este criterio para apreciar la existencia de daño por pérdida de la oportunidad y su valoración económica, teniendo en cuenta la doctrina y jurisprudencia francesa e italiana, puede verse en SerRa Rodriguez (2001 b), pp. 233-268. Propone, también, el recurso al "juicio sobre el juicio" como método para demostrar un perjuicio cierto YZquieRDo ToLSADA (1998a), p. 679. 49 SSTS 28.7.2003 (RJ 2003, 5989), 30.3.2006 (RJ 2006, 2129), 27.7.2006 (RJ 2006, 6548), 27.10.2011 (RJ 2001, 7313). Realizan un exhaustivo"juicio sobre el juicio" para acreditar el daño y cuantificarlo las SSTS 5.6.2013 (RJ 2013, 4971) y 14.10.2013 (RJ 2013, 7440). 50 Es más, como advierte Ángel YágǘzZ (2008), p. 40, "en no pocas veces un tribunal tiene que resolver también sobre la base

SERRA RODRÍGUEZ, Adela. La responsabilidad civil del abogado: algunas consideraciones sobre su naturaleza jurídica, el incumplimiento, la configuración del daño y su cuantificación en el Derecho español. Revista Justicia y Derecho, Santiago, v. $2, n^{\circ} 2,2019$ 
Es cierto que, como tienen declarado muchas de las sentencias apuntadas, nadie puede prever con absoluta seguridad que la demanda, el recurso o la reclamación judicial, frustradas o mal planteadas, hubieran sido acogidas, pero también lo es que, como dicen otras e incluso las mismas sentencias, sí pueden ser examinadas las posibilidades de que la acción o el recurso, de haber sido ejercitados diligentemente hubieran prosperado, como único medio para aproximarse al alcance de los daños. No se trata de que los Tribunales del orden civil realicen un exhaustivo enjuiciamiento de las pretensiones de las partes (una de ellas, el cliente-demandante), cuyo efectivo conocimiento por el órgano judicial no fue posible por la conducta negligente del letrado. Se trata más bien de realizar un análisis valorativo de la posición del cliente en aquel procedimiento, similar al que se realiza para determinar el resarcimiento del lucro cesante, con la finalidad de determinar si la pretensión frustrada era o no razonable y, en consecuencia, si a la conducta del letrado se le puede imputar objetivamente una efectiva pérdida de las oportunidades del cliente.

Por ello, si del examen de esta valoración se desprende que las probabilidades de éxito del recurso no interpuesto o de la acción frustrada por la negligencia del abogado eran nulas o escasas, no habrá perjuicio (por pérdida de oportunidad) y, en consecuencia, responsabilidad ${ }^{51}$. No habrá imputación objetiva del resultado dañoso a la conducta del abogado cuando el resultado desfavorable a las pretensiones del presunto dañado deba entenderse como razonablemente aceptable dentro del debate jurídico y no atribuible directamente, aunque no pueda afirmarse con absoluta seguridad, a la negligencia del profesional [STS 30.11.2005].

Es posible que del examen de la prosperabilidad de la pretensión frustrada por el abogado se desprenda que esta hubiera prosperado íntegramente (al 100\%) si el profesional hubiera actuado con la diligencia y pericia exigibles. En tal caso, la cuantía indemnizatoria coincidirá con la cuantía que dejó de percibir por el incumplimiento de aquél, pero el daño sufrido no será ya la "pérdida de la oportunidad", sino la privación de una ganancia cierta. Así lo han resuelto las SSTS 3.10.1998 (RJ 1998, 8587) y 30.11 .2005 (EDJ 207174).

Junto al método basado en el "juicio sobre el juicio" puede recurrirse al método estadístico para tener por acreditado el daño por la pérdida de la oportunidad, que se basa en un análisis objetivo del sentido de las resoluciones judiciales que conocieron de asuntos de idéntica naturaleza a aquel en que se produjo el incumplimiento del profesional ${ }^{52}$.

En mi opinión, ambos métodos o procedimientos son compatibles, en tanto que en el cálculo prospectivo del buen éxito de la acción o recurso frustrado deberá tenerse en cuenta los fallos de los tribunales en asuntos de misma naturaleza, atendiendo a las circunstancias concurrentes.

Por último, cabe tener en cuenta que la pérdida de la oportunidad podrá calificarse de daño moral, cuando el objeto de la pretensión o acción frustrada tenga dicha naturaleza, lo que podrá suceder, por ejemplo, si se frustró la acción de rectificación en una intromisión al honor o se dejó pasar el plazo para

de lo que habría ocurrido, pero no en relación con una incógnita jurídica, que para un órgano judicial es, por así decirlo, menos incógnita, sino sobre acontecimientos ajenos al mundo del derecho", poniendo como ejemplo el de la Medicina.

51 SSTS 27.7.2006 (RJ 2006, 6548), 26.2.2007 (RJ 2007, 2115), 23.7.2008 (RJ 2008, 7063) y 23.2.2010 (RJ 2010, 4341). Según la primera de las sentencias, si no se logra la prueba de que el perjudicado estaba en situación fáctica o jurídica idónea para realizar las oportunidades perdidas "no puede considerarse que exista perjuicio alguno, ni frustración de acción procesal, sino más bien un beneficio al supuesto perjudicado al apartarlo de una acción inútil, y ningún daño moral puede existir en esta privación, al menos en circunstancias normales".

52 Parece inclinarse por este recurso Gómez Pomar (2003) 7. La STS 20.5.2014 (RJ 2014, 3761) hizo uso de tal método para indemnizar a los actores con la cantidad que otras familias que se encontraban en idéntica situación habían obtenido en la vía contencioso-administrativa y que ellos no habían podido iniciar al haberles comunicado su abogado el archivo de las actuaciones penales cuando ya estaba prescrita la acción de responsabilidad patrimonial de la Administración.

SERRA RODRÍGUEZ, Adela. La responsabilidad civil del abogado: algunas consideraciones sobre su naturaleza jurídica, el incumplimiento, la configuración del daño y su cuantificación en el Derecho español. Revista Justicia y Derecho, Santiago, v. 2, n०2, 2019 
reclamar o impugnar la filiación no matrimonial. Tal razonamiento se desprende a sensu contrario de la STS 27.7.2006 (RJ 2006, 6548).

D) Algunos pronunciamientos consideran compatible el daño por la pérdida de la oportunidad, de carácter patrimonial y que implica una valoración de las actuaciones judiciales no emprendida, con el daño moral por la zozobra e incertidumbre de los defendidos, si consiguen acreditarlo. En tal sentido se pronuncia la mencionada STS 20.5.2014 (RJ 2014, 3761) 53.

\subsection{Otros daños derivados del incumplimiento profesional: los gastos y costas procesales}

El incumplimiento del abogado puede causar otro tipo de daños, claramente materiales o patrimoniales, cuya demostración, además, no suele ocasionar tantos problemas. Se trata de aquellos gastos que, por razón de la actuación del profesional, ha tenido que desembolsar el cliente y que pueden comprender tanto las costas procesales a las que fue condenado en el pleito en el que el profesional incurrió en negligencia o impericia ${ }^{54}$, como los gastos derivados del proceso en el que se exige responsabilidad al profesional (para el supuesto en que no fuera condenado en costas el abogado demandado). Estos gastos y costas procesales, siempre que se soliciten debidamente en el petitum de la pretensión y resulten acreditados, podrán quedar comprendidos en el ámbito de los daños resarcibles, en cuanto daño emergente derivado de la actuación negligente del abogado.

De otra parte, cuando el abogado desempeña actividades no jurisdiccionales (p. ej. asesoramiento fiscal) es posible que su actuación negligente ocasione daños patrimoniales, fácilmente valorables, como el importe de las sanciones económicas por retraso en la declaración fiscal o irregularidades cometidas o los intereses de demora, que también deberán ser resarcidos ${ }^{55}$.

\section{LA DETERMINACIÓN DEL QUANTUM INDEMNIZATORIO POR EL DAÑO POR LA PRIVACIÓN DE LA OPORTUNIDAD}

Una vez constatada la existencia de un perjuicio cierto, al quedar probado que el cliente tenía fundadas probabilidades de ver estimada su pretensión resta la valoración de la oportunidad perdida orden a fijar la cuantía indemnizatoria.

En ella, son dos los parámetros básicos que el tribunal deberá tener en cuenta: de una parte, las efectivas probabilidades de éxito de la pretensión o el recurso frustrado, expresadas en un porcentaje, y que ya habrá calculado para tener por acreditado el daño; de otra, la cuantía litigiosa de la pretensión frustrada (y que se podría haber obtenido con cierta probabilidad), teniendo siempre presente que esta última no puede venir identificada sin más con el perjuicio ocasionado al cliente (esto es, la "pérdida de

53 Existe una tendencia por parte de algunos tribunales españoles a aumentar la indemnización por daño moral de la víctima en casos de conductas dolosas o gravemente negligentes por el agente, sobre todo cuando el daño patrimonial es bajo o no ha quedado suficientemente acreditado. Aunque la función del Derecho de daños o la responsabilidad civil no sea punitiva, la de reprochar conductas, sino la de resarcir daños que éstas causan. Se cumple, con ello, con cierta función preventiva. En esta línea, se puede ver la mencionada Sentencia del Camping Las Nieves o la SAP Valencia 23.5.2016, que concedió una indemnización de 75000 euros por daño moral, atendiendo a las circunstancias concurrentes (graves lesiones sufridas por el demandante que determinaron una gran invalidez), pese a que la resolución sostiene que era difícil la estimación de la demanda no interpuesta por el letrado negligente y, por tanto, las probabilidades de éxito eran escasas.

54 SSTS 16.12.1996 (RJ 1996, 8971), 11.12.1997 (RJ 1997, 7871), 25.12.1998 (RJ 1998, 5013) y 18.6.2004 (RJ 2004, 3629).

55 Crespo Mora (2005a), p. 409.

SERRA RODRÍGUEZ, Adela. La responsabilidad civil del abogado: algunas consideraciones sobre su naturaleza jurídica, el incumplimiento, la configuración del daño y su cuantificación en el Derecho español. Revista Justicia y Derecho, Santiago, v. 2, n०2, 2019 
la oportunidad")56.

Las más recientes sentencias del Tribunal Supremo aluden al "principio de proporcionalidad", conforme al cual la indemnización se comprenderá dentro del abanico de probabilidades de estimación de la pretensión que no fue planteada por incuria del profesional. Así, resulta de las SSTS 27.7.2006 (RJ 2006, 6548) y 14.10.2013 (RJ 2013, 7440).

Si, como ya apuntamos, la operación de cálculo de oportunidades, a través del "juicio sobre el juicio" y del recurso a la estadística, arroja el resultado de que el cliente tenía un 100\% de probabilidades de ver estimada su pretensión, el daño sufrido ya no será la "pérdida de la oportunidad", sino la pérdida de la pretensión, la privación de un derecho, de una ganancia (ahora sí) efectiva y cierta dejada de obtener. Así, se ha resuelto en algunas sentencias ya mencionadas, y en otras en las que se llega a la conclusión por el juzgador de que la conducta del abogado fue la causa eficiente de la privación definitiva de un bien por el que se reclama y del lucro cesante, concretado en los rendimientos que del mismo se podrían haber obtenido [STS 19.2.2014 RJ 2014, 1129) $)^{57}$.

En el caso de que la pretensión frustrada sea de carácter extrapatrimonial la valoración tendrá en cuenta el primer parámetro (esto es, las probabilidades de éxito) y no el segundo. Su cuantificación se hará en términos semejantes al daño moral.

\section{Conclusiones}

Desde mediados de los años noventa del siglo XX se ha venido consolidando en España la tendencia a exigir responsabilidad civil al abogado por su negligencia o impericia en el desarrollo de su actividad profesional, teniendo en cuenta, en todo caso, que la obligación que asume es de medios o actividad y que, sólo en determinados supuestos (ej. elaboración de un dictamen) se obligan a procurar un resultado.

En la exigencia de responsabilidad a estos profesionales la jurisprudencia y la doctrina han ido perfilando aquellas conductas (activas $u$ omisivas) que se consideran incumplimiento de las reglas de la profesión, de la lex artis ad hoc, y, por tanto, son generadoras de responsabilidad civil, si concurren otros dos presupuestos (daños y nexo causal).

En efecto, los dos mayores obstáculos para afirmar la responsabilidad del abogado es la acreditación del daño ocasionado al cliente y de la relación de causalidad entre la conducta negligente y el daño alegado. En este sentido, en la actualidad es mayoritaria la tesis que sostiene que, cuando el abogado con

56 SSTS 27.7.2006 (RJ 2006, 6548) y 21.6.2007 (RJ 2007, 3781). La primera valora el daño por la pérdida de la oportunidad, que califica de "patrimonial", en función de las "posibilidades de buen éxito del recurso interpuesto en relación con el interés económico objeto de reclamación". A tal fin, efectúa una previsión en relación con las posibilidades de éxito del recurso de casación tardíamente presentado, teniendo en cuenta el importe de la condena recaída, la naturaleza del asunto, las características limitadas del recurso de casación y el examen del dictamen Colegio del Abogados, concluyendo las escasas posibilidades de éxito de aquel recurso extemporáneamente presentado. Pese a ello, fija la indemnización en 12.000 €"indemnización similar a la otorgada en supuestos similares de escasas posibilidades de procedibilidad del recurso". Misma cantidad condenó el TS en la Sentencia 21.6.2007 (RJ 2007, 3781).

57 En esta Sentencia el TS casó la sentencia de instancia, que había condenado al abogado a una cantidad bastante inferior a la solicitada, entendiendo que la conducta del profesional causó a la actora un daño emergente, consistente en el valor actualizado de una vivienda de que fue privada por la negligencia de aquél, y el lucro cesante por los rendimientos en forma de alquiler que hubiera podido obtener. Ambos daños se estiman previsibles por el letrado en el momento de contratar y consecuencia de su incumplimiento contractual y, por tanto, resarcibles.

SERRA RODRÍGUEZ, Adela. La responsabilidad civil del abogado: algunas consideraciones sobre su naturaleza jurídica, el incumplimiento, la configuración del daño y su cuantificación en el Derecho español. Revista Justicia y Derecho, Santiago, v. $2, n^{\circ} 2,2019$ 
su conducta omisiva o extemporánea provoca que el cliente no pueda ver examinada su pretensión o recurso por un órgano judicial, el daño ocasionado es la pérdida de la oportunidad lo que exige, a diferencia del daño moral, una indagación de las efectivas oportunidades que tenía el cliente de ver estimada su pretensión o el recurso non nato o inadmitido, un cálculo prospectivo de las probabilidades de que aquella o este fueran acogidos por el tribunal. Operación intelectual llevada a cabo por el juzgador civil que conoce de la pretensión indemnizatoria y que se conoce como el "método del juicio sobre el juicio", que atiende a todas las circunstancias del caso concreto.

Este daño por la pérdida de la oportunidad es distinto al daño moral por la angustia, zozobra, incertidumbre, ansiedad o frustración sufridas por el cliente del letrado negligente, que, a mi juicio, solo será indemnizable si se demuestra que con su conducta incrementó el riesgo de producción de dicho daño, un estado de incertidumbre no necesaria, más allá de estar inmerso en un proceso judicial.

Por último, algunas sentencias consideran que la mera privación del derecho al acceso a la tutela judicial, a que la causa sea examinada por un tribunal es un daño calificado de moral, sin exigir una indagación de las oportunidades perdidas.

\section{Bibliografía Citada}

Alonso Pérez, Ma Teresa (1997): Los contratos de servicios de abogados, médicos y arquitectos (Barcelona, Bosch).

Ángel Yágüez, Ricardo De (2008): "La responsabilidad civil del abogado", Indret, pp. 1-54. Disponible en: http://www.indret.com/pdf/521_es.pdf

Crespo Mora, Ma Carmen (2005): La responsabilidad del abogado en el Derecho civil (Madrid, Thomson-Civitas).

Dupuy de Lome Manglano, Santiago (2014): "Sobre la consideración del daño en la responsabilidad civil del abogado: ¿daño moral o daño patrimonial", en LA LEY 8584/2014, pp. 1-8.

Gómez Pomar, Fernando (2003): "Pleitos tengas: pérdida de un litigio, responsabilidad del abogado y daño moral. Comentario a la STS de 8 de abril de 2003", Indret, pp. 1-9. Disponible en http://www.indret.com/ pdf/154_es.pdf.

Moreo ArizA, Javier (2007): "La compleja configuración del daño en la responsabilidad civil del abogado", Indret, pp. 1-24. Disponible en: http://www.indret.com/pdf/414_es_1.pdf.

Rebolledo Varela, Ángel Luis (1997): “Comentario S.T.S. de 16 de diciembre de 1996”, en CCJC, núm. 44, pp. 475-500.

Reglero Campos, Fernando. (2007): "La responsabilidad civil de abogados en la jurisprudencia del Tribunal Supremo", Revista de la Asociación española de abogados especializados en responsabilidad civil y seguro, núm. 21, pp. 21-43. Disponible en: http://www.asociacionabogadosrcs.org/portal/wpcontent/ uploads/2017/06/revista21.pdf

Serra Rodríguez, Adela (1999): La relación de servicios del abogado (Valencia, Tirant Lo Blanch).

Serra Rodríguez, Adela (2001): La responsabilidad civil del abogado (Cizur Menor (Navarra), Aranzadi, 2a ed.).

Vicente Domingo, Elena (2014): "El daño", Tratado de responsabilidad civil, en Reglero Campos, Fernando y Busto Lago, José Manuel (coords.), (Cizur Menor-Navarra, Thomson Reuters Aranzadi, 5a ed, vol. 1), pp. 
317-462.

Yzquierdo Tolsada, Mariano (2004): "Responsabilidad civil de abogados y procuradores. El quid, pero sobre todo el quantum", Ponencia del IV Congreso de la Asociación de abogados especializados en responsabilidad civil y seguro, http://www.asociacionabogadosrcs.org/antig/congreso/4congreso/ponencias4. html.

\section{NoRMAS CITADAs}

Código civil (CC)

Ley 2/1974, de 13 de febrero, sobre Colegios Profesionales.

Constitución Española de 27 de diciembre de 1978 (CE).

Ley Orgánica 6/1985, de 1 de julio, del Poder Judicial (LOPJ).

Ley 30/1992, de 26 de noviembre, de Régimen jurídico de las Administraciones Públicas y Procedimiento Administrativo Común.

Ley 1/1996, de 10 de enero, de Asistencia Jurídica Gratuita (LAJG).

Ley 1/2000, de 7 de enero, de Enjuiciamiento Civil (LEC).

Real Decreto 685/2001, de 22 de junio, por el que se aprueba el Estatuto General de la Abogacía Española (EGA).

Código Deontológico de la Abogacía española, aprobado por el Pleno del Consejo General de la Abogacía Española, de 27 de septiembre de 2002.

Código Deontológico de la Abogacía española, aprobado por el Pleno del Consejo General de la Abogacía Española, de 6 de marzo de 2019.

Ley 2/2007, de 15 de marzo, de Sociedades Profesionales (LSP).

Ley 25/2009, de 22 de diciembre, de modificación de diversas leyes para adaptarlas a la Ley sobre el libre acceso a las actividades de servicio y su ejercicio.

Ley 40/2015, de 1 de octubre, de Régimen Jurídico del Sector Público (LRJSP).

\section{JURISPRUDENCIA CITADA ${ }^{58^{*}}$}

STS 4.2.1992 (RJ 1992, 819)

STS 17.11.1995 (RJ 1995, 8735)

STS 12.5.1997 (RJ 1997, 3838)

STS 28.1.1998 (RJ 1998, 357)

58 "STS: Sentencia del Tribunal Supremo; SAP: Sentencia de la Audiencia Provincial; RJ: Repertorio de Jurisprudencia (Aranzadi); AC: Aranzadi Civil; JUR: Sentencias y Autos de la Audiencia Nacional, Tribunales Superiores de Justicia, Audiencias Provinciales y Juzgados (Aranzadi); EDJ: El Derecho Repertorio Jurisprudencial.

SERRA RODRÍGUEZ, Adela. La responsabilidad civil del abogado: algunas consideraciones sobre su naturaleza jurídica, el incumplimiento, la configuración del daño y su cuantificación en el Derecho español. Revista Justicia y Derecho, Santiago, v. 2, n०2, 2019 
STS 25.3.1998 (RJ 1998, 1651)

STS 14.5.1999 (RJ 1999, 3106)

STS 8.2.2000 (RJ 2000, 842)

STS 8.6.2000 (RJ 2000, 5098)

STS 23.5.2001 (RJ 2001, 3372)

STS 2.2.2001 (EDJ 2001, 37636)

STS 25.4.2002 (EDJ 2002/10139)

STS 12.12.2003 (RJ 2003, 9285)

STS 28.4.2005 (RJ 2005, 3646)

STS 14.7.2005 (RJ 2005, 6532)

STS 30.11.2005 (EDJ 207174)

STS 27.7.2006 (RJ 2006, 6548)

STS 26.2.2007 (RJ 2007, 2115)

STS 23.3.2007 (RJ 2007, 1542)

STS 23.7.2008 (RJ 2008, 7063)

STS 23.2.2010 (RJ 2010, 4341)

STS 27.5.2010 (RJ 2010, 5160)

STS 27.10.2011 (RJ 2011, 7313)

STS 22.4.2013 (RJ 2013, 3690)

STS 14.10.2013 (RJ 2013, 7440)

STS 19.11.2013 (RJ 2013, 7448)

STS 19.2.2014 RJ 2014, 1129)

STS de 20.5.2014 (RJ 2014, 3761)

STS 24.4.2015 (RJ 2015, 2388)

STS 1.7.2016 (RJ 2016, 3721)

SAP Jaén 7.11.1994 (AC 1994, 1929)

SAP Málaga de 26.4.1996 (AC 727, 1996)

SAP León de 17.3.1997 (AC 1997, 422)

SAP Huesca de 26.6.2000 (EDJ 2000/22883)

SAP Segovia de 26.1.2000 (AC 2000, 96)

SAP Valencia de 23.5.2016 (AC 2017, 484)

SERRA RODRÍGUEZ, Adela. La responsabilidad civil del abogado: algunas consideraciones sobre su naturaleza jurídica, el incumplimiento, la configuración del daño y su cuantificación en el Derecho español. Revista Justicia y Derecho, Santiago, v. $2, n^{\circ} 2,2019$ 